\title{
LABOR MOBILITY OF FOREIGNERS IN SLOVAK REPUBLIC
}

\author{
Eva Rievajová \\ Andrej Př́ivara \\ University of Economics in Bratislava, Bratislava, Slovak Republic \\ Kamila Mayerová \\ Alexander Dubček University of Trenčín, Trenčín, Slovak Republic
}

The issue of international labor migration is currently one of the most serious and discussed issues in all EU countries. This is also the case in Slovakia. The paper focuses primarily on the description of the current development of Slovak migration policy, which reflects the current situation at Slovak labor market. The impact of the simplified recruitment of workers from third countries for their employment in Slovakia is documented on the basis of the latest statistics. We consider efforts to modernize migration policies as one of the possible means of addressing the situation of labor shortages at Slovak labor market.

Keywords: international labor migration; migration policy; labor market; labor shortages; Slovakia.

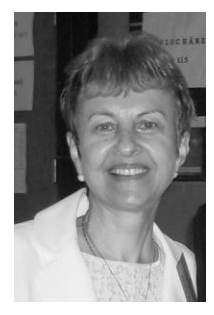

\section{Eva Rievajová}

$\mathrm{PhD}$, lecturer Faculty of National Economy, Department of Social Development and Labour, University of Economics in Bratislava, Slovak Republic

Research interests: labor markets globalization, migration policy

E-mail: eva.rievajova@euba.sk

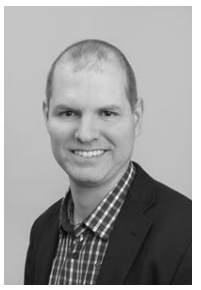

Andrej Př́ívara

$\mathrm{PhD}$, ast. professor, Department of Social Development and Labour, University of Economics in Bratislava Bratislava, Slovak Republic

Research interests: international migration, EU labor market, international regulation of labor migration

E-mail: andrej.privara@euba.sk

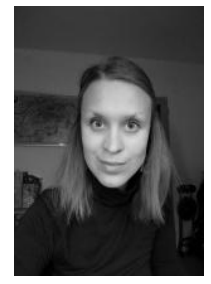

Kamila Mayerová

Ing, lecturer Faculty of Social Economics Relationships, Alexander Dubček University of Trenčín

Trenčín, lovak Republic

Research interests: labor markets globalization, migration policy

E-mail: kamila.mayerova@tnuni.sk 


\section{LABOR MOBILITY OF FOREIGNERS}

\section{Introduction}

With advanced technologies, new and faster transportation means and the Internet, migration is now getting much greater volumes than it used to have in the past. We are currently witnessing constant increases in migrants heading to Europe, which is commonly referred to as the "European migration crisis". People are fleeing from the countries where there is a war or where they are being threatened due to various reasons. However, that is only one of many forms of migration; thus, very different people are migrating to Europe and for various reasons.

The present time is also commonly referred to as the mobility era.

Mobility and migration are currently most intense as compared to other periods of human history, and these two phenomena manifest themselves in various areas of our lives.

More and more companies today employ people from different countries, are opening branches worldwide, and collaborate at global markets. Newest advanced technologies have enabled employees communicate with each other and with headquarters from anywhere in the world. The global economy also means a wider talent pool that is not limited by national borders but is open to all. In other words, employees can work for companies based outside the countries of employees' actual residence.

Workforce mobility can help reduce operational and overhead costs by enabling employees to work remotely and increase productivity by improving access to resources.

The aim of this paper is to draw attention to the institutional framework and intentions of Slovak migration policy and the process of recruitment of third-country workers to Slovak labor market.

\section{Institutional Framework of the Migration Policy in Slovak Republic}

The basic document of Slovak Republic, which regulates labor migration in the country, is currently the Migration Policy of the SR with a view to 2020. It was approved on August 31, 2011 by the Government Resolution No. 574. In this document, the key idea is that Slovak labor market is dependent on the influx of human capital from abroad. The main reason is the currently unfavorable demographic development in Slovakia. Therefore, it is essential that Slovakia implements policies geared towards recruitment and employment of migrants from third countries, in line with the needs of the local labor market and with an emphasis on highly skilled workers in the first place (Bolečeková et al., 2018; Danaj et al., 2018; De La Peña Esteban \& Peña-Miguel, 2018).

The aims of the migration policy in Slovak Republic are to ensure:

- protection of national interests of Slovak Republic and the implementation of objectives and priorities in the area of migration, as well as their provision by individual entities involved in implementation of migration policy,

- creation of conditions in the area of human, material and financial resources and coordination of competent institutions in this area,

- active participation of Slovak Republic in the law-making of the European Community and more specifically - in the European Union legislation work in the field of migration,

- further harmonization of Slovak legislation with the laws of the European Communities and the European Union in the area of migration, 
- development of the institutional framework necessary to implement policies in this area.

Migration policy of the SR with a view to 2020 has become the starting document for several governmental departments which have been elaborating action plans containing more detailed definition of individual tasks. The time-wise, factual and financial fulfillment of tasks, intentions and objectives of migration policy are annually the subject of a summary report submitted by the Minister of the Interior to the Government (Bachtíková, 2014).

In connection with the modernization of Slovak migration policy, it is also necessary to mention another document, which is the Economic Policy Strategy of Slovak Republic until 2030. Its recommendations emphasize that: "To maintain its competitiveness, Slovakia must also reflect on the migration movements of skilled labor from other countries to the EU and not lag behind in exploiting this potential. Rejecting skilled workforce, especially when the SR feels its shortage, in relation to real and not nominal unemployment, could represent an immediate barrier to its economic development. Therefore, it is important that the stateguided immigration policy reflects these facts by establishing ways and conditions appropriate to the economic interests of the SR and its population".

Another important part of the migration policy in Slovak Republic is the Strategy of Labor Mobility of Foreigners in Slovak Republic approved by the Government Resolution No. 473 as of October 10, 2018.

The strategy includes 23 short-term measures to be taken into account by the government by 2020 and also 27 long-term measures with a view to 2030. Unlike other V4 countries, Slovakia remains the country that regulates the supply of legal qualified labor force from third countries, which will not cause social dumping at Slovak labor market. The aim is to create the first strategic document for Slovak Republic in the field of regulated labor mobility of foreigners at the labor market of Slovak Republic (Wang, 2019).

The target group of this strategy does not consist of refugees and/or asylum seekers.

The strategy focuses on the controlled (regular/legal) labor mobility of foreigners aimed at compensating for the lack of available labor at the labor market in Slovakia.

The short-term goal of the Strategy is to adopt temporary, extraordinary (hot-fix) measures to address the current shortage of skilled labor at Slovak labor market, with a view to later considering the need to maintain the extraordinary measures taken, given the current needs of the labor market or the current number of foreigners in Slovakia (Klamár \& Gaval'ová, 2018; Sirkeci \& Př́ivara, 2017; Šprocha et al., 2018).

It is too early to evaluate the effectiveness of the mentioned Strategy. Nevertheless, SWOT-analysis prepared by the Ministry of Labor, Social Affairs and Family of the SR (Tab. 1) which has determined strengths, weaknesses, opportunities and risks from labor mobility of foreigners to Slovak labor market seems to us to be very stimulating, to say the least.

Slovak labor market is currently experiencing an extremely successful period. The main reason for it is the economic recovery overall. Slovak economy today is in a situation when more and more businesses have to reject contracts due to lack of staff, and this can undoubtedly have a negative impact on further economic growth rates. By the end of 2018, companies were not obliged to report job vacancies to labor offices, but now they are required to do so by law. Thus, about 90,000 vacancies have been registered by the end of April 2019. 


\section{LABOR MOBILITY OF FOREIGNERS}

\section{Table 1. SWOT-analysis of the Labor mobility strategy for foreigners in Slovak Republic}

(Source: Own elaboration based on the data from the MPSVR, 2019)

\begin{tabular}{|c|c|}
\hline Strengths & $\begin{array}{l}\text { - } \quad \text { broad infrastructure of Labor, Social Affairs and Family Offices across the regions of } \\
\text { Slovakia } \\
-\quad \text { political guarantees for implementation of the related measures } \\
-\quad \text { introduction of strategic solutions to the problems of the skilled labor shortages at } \\
\text { Slovak labor market } \\
-\quad \text { use of expert recommendations } \\
-\quad \text { interconnection of the proposed measures and recommendations with other strategic } \\
\text { documents of the country } \\
\text { - close links and cross-cutting cooperation among stakeholders (Vasylieva \& } \\
\text { Samusevych, 2018) }\end{array}$ \\
\hline Weaknesses & $\begin{array}{l}\text { - } \quad \text { excessive number of measures and recommendations due to long-term } \\
\text { underestimation of strategic planning in the area of labor mobility of foreigners } \\
\text { - } \quad \text { lack of cooperation and poor exchange of information by central government } \\
\text { authorities on labor mobility situation and integration of foreigners in the country } \\
-\quad \text { unconnectedness of information systems and ambiguous identification of foreigners } \\
\text { - } \quad \text { lack of personnel capacities and skills }\end{array}$ \\
\hline Opportunities & 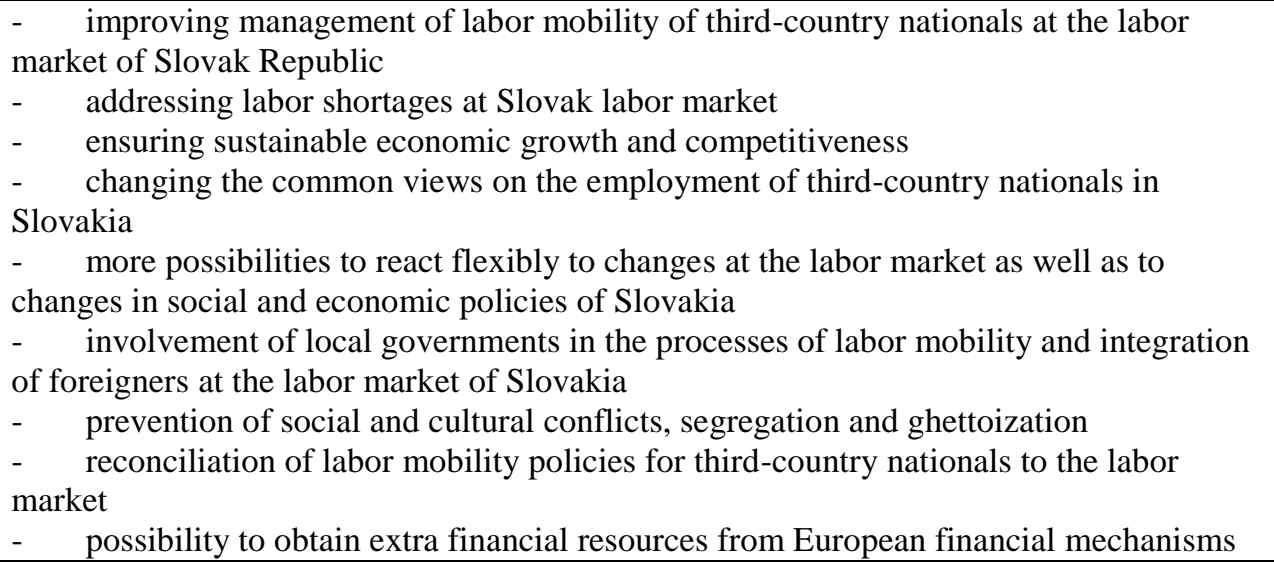 \\
\hline Threats & 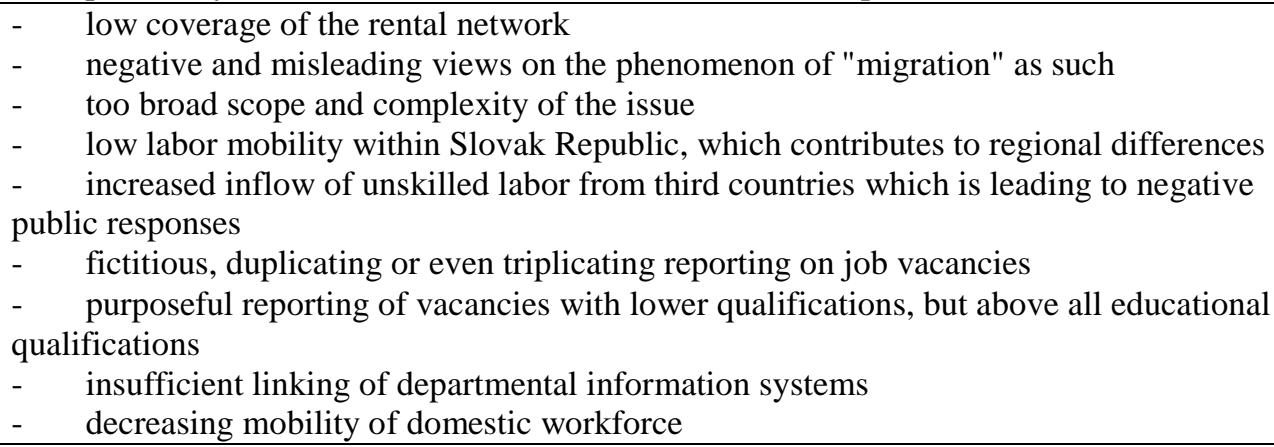 \\
\hline
\end{tabular}

Given the existing shortage of workers at Slovak labor market, low and declining unemployment, departure of valuable human resources from the local labor market, and inadequate level of preparation among school graduates, many companies in Slovakia can be expected to show increased interest in economic migrants. 


\section{Recruitment of workers from third countries}

Despite the fact that Slovakia has had a defined migration policy since 2011, it is still complicated for foreigners from third countries to enter this labor market. Due to timeconsuming administrative measures, employers often have to wait for an employee from third countries for, on average, up to 145 days.

In real business practice, companies simply cannot find suitable candidates for some positions as such. Therefore, since May 1, 2018, recruitment of third-country workers for the professions experiencing significant understaffing was simplified. However, this applies only to the districts with an average registered unemployment rate of less than $5 \%$.

The list of jobs, where labor shortages are persisting, was set by a special Commission and then published on the website of the Central Office of Labor, Social Affairs and Family. It is updated on the annual basis (Bucevska, 2011; Crespo Cuaresma et al., 2014).

Employment of foreigners from outside the EU has been simplified in 2019 only, by amending several related laws. The most important changes are: more frequent updating of this list of jobs with shortages -- from annual to quarterly; assessment of the registered unemployment rate, comparing it with the previous calendar quarter; employers are again obliged to report vacancies to the affiliated labor offices; possibilities for hiring workers through temporary employment agencies have been expanded. These days an employer cannot employ more than $30 \%$ of foreigners from the total number of their employees. An important step is to reduce the waiting time for assessing applications for temporary residence of a foreigner coming to work -- from the original 90 days to 30 days -- due to quite significant workforce shortages (Kakaš, 2017; Kelly \& Hedman, 2016; Rehák \& Dudová, 2018; Škuflić \& Vučković, 2018).

The list of professions with a limited supply today concerns 47 districts in six regions of Slovakia. The most of professions with limited supply are located in the Bratislava Region. There are 103 such professions here, including jobs in healthcare, transportation, construction and social services. In the districts of the Trnava Region, there are 65 professions with supply shortages, particularly in healthcare, transportation and construction sectors. There are 64 professions with shortages in the districts of the Nitra Region, again, in healthcare and transportation primarily, but also in engineering and gastronomy. There are 65 professions with troublesome supply in the districts of the Trenčín region, again healthcare and transportation, but also such job positions as glassmaker, butcher and baker. Districts in the Žilina Region have registered 53 professions with shortages -- in healthcare, transportation, construction and engineering. Finally, the district of Banská Bystrica has 51 professions experiencing HR shortages, mainly in healthcare, transportation and engineering.

The first impacts of simplified recruitment of third-country workers at Slovak labor market are shown in Tab. 2 and 3. 


\section{LABOR MOBILITY OF FOREIGNERS}

Table 2 - Employment of third-country nationals in 2018 and 2019, by regions (Source: Own processing of the UPSVAR data, 2019)

\begin{tabular}{|c|c|c|c|c|c|c|}
\hline \multicolumn{7}{|c|}{$\begin{array}{l}\text { Employment of third-country nationals with work permits on the territory of Slovak } \\
\text { Republic, by regions }\end{array}$} \\
\hline \multicolumn{5}{|c|}{2018} & \multicolumn{2}{|c|}{2019} \\
\hline REGION & 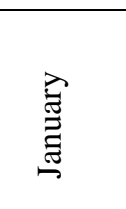 & 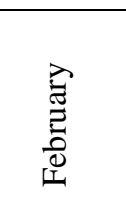 & 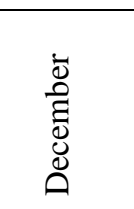 & $\begin{array}{l}\bar{\Delta} \\
\text { है } \\
\text { Dे } \\
\text { zे } \\
\text { z }\end{array}$ & 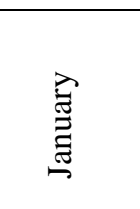 & 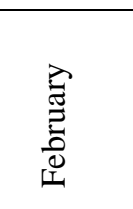 \\
\hline Bratislava Region & 2,874 & 2,949 & 5,769 & 5,365 & 6,085 & 6,499 \\
\hline Trnava Region & 2,193 & 2,198 & 3,480 & 3,280 & 3,555 & 3,529 \\
\hline Trenčín Region & 756 & 812 & 2,246 & 2,006 & 2,389 & 2,622 \\
\hline Nitra Region & 688 & 602 & 1,891 & 2,240 & 1,935 & 1,998 \\
\hline Žilina region & 775 & 780 & 1,228 & 1,171 & 1,268 & 1,286 \\
\hline $\begin{array}{l}\text { Banská Bystrica } \\
\text { Region }\end{array}$ & 456 & 508 & 818 & 771 & 877 & 898 \\
\hline Prešov Region & 487 & 560 & 700 & 649 & 714 & 831 \\
\hline Košice Region & 609 & 622 & 932 & 902 & 960 & 1,002 \\
\hline TOTAL & 8,838 & 9,031 & 17,064 & 16,384 & 17,783 & 18,665 \\
\hline
\end{tabular}

We can see from the table above that employment of third-country nationals has a growing tendency. For comparison, in January 2018 there were 8,838 foreigners from third countries in Slovakia while in January 2019 there were already 17,783 foreigners in total. In February 2018, there were 9,031 foreigners, and in February 2019 their number was already 18,665 , which is more than two-fold increase. The most of employed foreigners were residing in the Bratislava Region and the smallest number of foreigners was recorded in the Prešov Region, which is also in line with the general unemployment rates of these regions in Slovakia.

Data presented in Tab. 3 shows that the number of foreigners from the EU countries working in Slovak Republic is increasing every year. The majority of such foreigners were residing in the Bratislava Region and the lowest their numbers were recorded in the Žilina, Prešov and Košice regions. For comparison, in January 2018 there were 27,839 foreigners working in Slovakia while in January 2019 this number was 36,148. In other words, in one year alone their number increased by 8,309 foreigners. In February 2018, 28,198 foreigners were employed in Slovakia, while in February 2019 there were already 35,061 of them, thus, the increase is 6,863 foreign citizens. 
Table 3 - Employment of the EU/EEA citizens in 2018 and 2019, by Slovak regions (Source: own processing of the UPSVAR data, 2019)

\begin{tabular}{|c|c|c|c|c|c|c|}
\hline \multirow[b]{2}{*}{ REGION } & \multicolumn{2}{|c|}{2019} & \multicolumn{4}{|c|}{2018} \\
\hline & 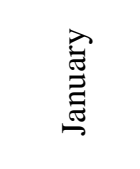 & $\begin{array}{l}\vec{E} \\
\stackrel{\vec{E}}{E} \\
\text { 0. } \\
\text { L }\end{array}$ & 壳 & 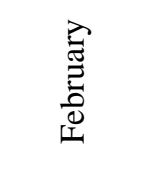 & 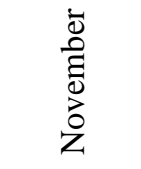 & $\begin{array}{l}\bar{\Xi} \\
\text { है } \\
\text { صूँ } \\
\end{array}$ \\
\hline Bratislava Region & 17,1 & 15,744 & 10,516 & 10,764 & 14,875 & 17,183 \\
\hline Trnava Region & 4,984 & 4,987 & 4,771 & 4,642 & 5,162 & 5,118 \\
\hline Trenčín Region & 2,359 & 2,357 & 2,003 & 2,014 & 2,414 & 2,299 \\
\hline Nitra Region & 4,826 & 5,074 & 4.557 & 4,724 & 4,83 & 4,831 \\
\hline Žilina region & 1,733 & 1,771 & 1,393 & 1,357 & 1,714 & 1,69 \\
\hline $\begin{array}{l}\text { Banská Bystrica } \\
\text { Region }\end{array}$ & 1,589 & 1,597 & 1,367 & 1,391 & 1,547 & 1,534 \\
\hline Prešov Region & 1,669 & 1,615 & 1,632 & 1,659 & 1,651 & 1,731 \\
\hline Košice Region & 1,888 & 1,916 & 1,6 & 1,647 & 1,869 & 1,879 \\
\hline TOTAL & 36,148 & 35,061 & 27,839 & 28,198 & 34,062 & 36,265 \\
\hline
\end{tabular}

There are many reasons why the number of foreigners employed in Slovakia is increasing. These days Slovak labor market is experiencing the lack of mainly qualified workers and those with secondary vocational qualifications in particular (toolmakers, metalworkers, electromechanical technicians, CRM operators etc.). These are mainly positions in the automotive, mechanical and electrical industries. IT specialists are also in short supply. There is also a shortage of truck drivers, vendors, craftsmen and electricians. High turnover is another serious problem with production and business professions. The immediate need for the workforce in the positions with the greatest shortages is between 750 and 1,000 workers. One of the reasons for this is the fact that Slovak labor force is not interested in working for a minimum wage and is also not interested in working in lower and the so-called "inferior" positions, therefore, such job positions are occupied by foreigners.

The employment rate among the foreigners living and working in Slovakia last year (2018) reached $80.8 \%$, which is more than 8.4 percentage points higher than the employment rate among the domestic population. In Slovakia as well as in Czech Republic the employment rate of foreigners is the highest among all EU countries. The reason for this fact is in stricter conditions for legal residence of foreigners and also the fact that they already come to Slovakia due to performance of a particular job or business as opposed to other EU countries (such as Germany, Sweden, Italy, Denmark) where they mostly seek a work position upon arrival into the country. Most foreigners from third countries working in Slovakia come from such countries as Ukraine, Serbia, Vietnam and Bosnia and Herzegovina (Deskar-Škrbić et al., 2018; Hudcovský et al., 2017; Klamár \& Gaval'ová, 2018). 


\section{LABOR MOBILITY OF FOREIGNERS}

\section{Conclusions}

Migration of people is generally regarded as one of the hallmarks of globalization processes in the world. Several factors contribute to it, e.g., elimination of administrative barriers, increasing economic integration and demand for labor, perceptible population growth, overcrowding in certain countries, armed conflicts, persecution and discrimination, rapid development of transport and information technologies, social networking, migrant communities and more.

Migration is not a new phenomenon as people and groups of people have always migrated throughout history. We can say that for the most time of human existence, people have had a more nomadic way of life for much longer than a settled way of living in communities and societies.

Migration has many benefits for today's societies. For example, it compensates for the lack of domestic workforce, contributes to economic development, dissemination of knowledge and innovations. Mass migration of people from less developed countries to the countries that are more economically developed and which can guarantee their citizens higher quality of life is considered to be its other side. Therefore, all countries, including Slovakia, are trying to regulate migration in different ways, in order to exploit its benefits and at the same time to avoid its negative effects, such as uncontrolled migration, which in turn can complicate integration of migrants in a new country, cause conflicts, increase the target country's costs etc.

So far, Slovakia has not been a traditional destination for migrants. It is a culturally homogeneous country that has not been affected by dramatic increase in migration inflows during the 20th century or during the migration crisis since 2015.

Until recently, Slovak Republic was almost exclusively a country of origin for migrants- a country from which the citizens migrated abroad for various reasons. At present, the situation is changing, thus requiring new approaches and solutions to recruitment and employment of foreigners.

\section{Acknowledgments}

This paper is the output of the Vega research project no. 1/0001/16: "Present and prospective changes in employment and related processes in the context of meeting the objectives of the European Employment Strategy".

\section{References:}

Bachtíková, I. (2014). Organizácia azylovej a migračnej politiky v Slovenskej republike. Bratislava: IOM.

Bilic, M., Krogmann, A. (2015). Zahraničná migrácia a jej vplyv na životnú úroveň obyvatel'ov a krajinu Slovenska. Nitra: Univerzita Konštantína Filozofa v Nitre.

Bolečeková, M., Olejárová, B., \& Ostasz, G. (2018). Instruments of migration policy: A case of the Slovak Republic. Journal of International Studies, 11, 225-239.

Bucevska, V. (2011). The Role of Remittances in Financial Crisis: Empirical Evidence from Macedonia. Economic Research-Ekonomska Istraživanja, 24(4): 75-90. 
Crespo Cuaresma, J., Lábaj, M., \& Pružinský, P. (2014). Prospective ageing and economic growth in Europe. The Journal of the Economics of Ageing, 3(C): 50-57.

Danaj, A., Lazányi, K., \& Bilan, Y. (2018). Perceptions and Implications of Immigration in France - Economic, Social, Political and Cultural Perspectives. Economics \& Sociology, 11(3): 226-247.

De La Peña Esteban, J. I., \& Peña-Miguel, N. (2018). Rethinking social welfare in Spain: a basic pension for everyone. Economic Research-Ekonomska Istraživanja, 31(1): 17371757.

Deskar-Škrbić, M., Drezgić, S., \& Šimović, H. (2018). Tax policy and labour market in Croatia: effects of tax wedge on employment. Economic Research-Ekonomska Istraživanja, 31(1), 1218-1227.

Drozd, P., Frkáňová, A., \& Ulrichová, N. (2013). Získavanie vysokokvalifikovaných a kvalifikovaných štátnych príslušníkov tretích krajín do Slovenskej republiky. Bratislava: IOM.

FINWEB. (2018). Ktoré profesie nemá na Slovensku kto robit? Zverejnili očakávaný zoznam. Retrieved: https://finweb.hnonline.sk/ekonomika/1769005-ktore-profesienema-na-slovensku-kto-robit-zverejnili-ocakavany-zoznam

Hudcovský, M., Lábaj, M., \& Morvay, K. (2017). Employment Growth and Labour Elasticity in V4 Countries: Structural Decomposition Analysis. Prague Economic Papers, 26(4): 422-437.

IOM (2019a). Modrá karta EÚ. Retrieved: https://www.mic.iom.sk/sk/pobyt2/prechodnypobyt/167-modra-karta-eu.html

IOM (2019b). Zamestnávanie cudzincov na Slovensku. Retrieved: https://www.mic.iom.sk/sk/praca/zamestnavanie-cudzincov-na-slovensku.html

Kakaš, A. (2017). Vzdialenost' ako faktor vỳskumu vnútornej migrácie Slovenska. Geografickỳ Casopis, 69(1): 41-60.

Kelly, M., \& Hedman, L. (2016). Between Opportunity and Constraint: Understanding the Onward Migration of Highly Educated Iranian Refugees from Sweden. Journal of International Migration and Integration, 17(3), 649-667.

Klamár, R., \& Gaval'ová, A. (2018). Regional application of the Gross National Happiness Index in the context of the quality of life in Slovakia. Geografický Časopis Geographical Journal, 70(4).

MHSR (2018). Stratégia hospodárskej politiky Slovenskej republiky do roku 2030. Retrieved: https://www.mhsr.sk/uploads/files/wRKb2ncO.pdf

MPSVR (2019a). Stratégiu pracovnej mobility cudzincov v Slovenskej republike. Retrieved: https://www.employment.gov.sk/files/slovensky/uvod/informaciecudzinci/strategia.pdf

Pohorelá, P. (2019). Povinnosti zamestnávatel’a pri zamestnávaní cudzincov v roku 2019. Retrieved: https://www.podnikajte.sk/zakonne-povinnosti-podnikatela/zamestnavaniecudzincov-2019

Rehák, Š., \& Dudová, I. (2018). Kto ostáva a kto odchádza? Migračné rozhodovanie absolventov Žilinskej univerzity v Žiline. Geografický Časopis - Geographical Journal, 70(1).

Sirkeci, I., \& Přívara, A. (2017). Cost of Sending Remittances from the UK in the Aftermath of the Financial Crisis. Remittances Review, 2(1): 47-56. 


\section{LABOR MOBILITY OF FOREIGNERS}

Škuflić, L., \& Vučković, V. (2018). The effect of emigration on unemployment rates: the case of EU emigrant countries. Economic Research-Ekonomska Istraživanja, 31(1), $1826-1836$.

Šprocha, B., Š́́dlo, L., Klapková, M., \& Ďurček, P. (2018). Nové prístupy k hodnoteniu procesu populačného starnutia a ich aplikácia $\mathrm{v}$ prípade Slovenska a Európy. Geografický Časopis - Geographical Journal, 70(4).

Vasylieva, T., \& Samusevych, Y. (2018). Does Tax Competition for Capital Define Entrepreneurship Trends in Eastern Europe? On-Line Journal Modelling the New Europe, (27), 34-66.

Wang, D. (2019). International labour movement, public intermediate input and wage inequality: a dynamic approach. Economic Research-Ekonomska Istraživanja, 32(1), $1-16$.

Paper submitted

Paper accepted for publishing

Paper published online
16 June 2019

13 August 2019

01 October 2019 